2005

\title{
Truth or Consequences in Legal Scholarship?
}

David R. Barnhizer

Cleveland State University, d.barnhizer@csuohio.edu

Follow this and additional works at: https://engagedscholarship.csuohio.edu/fac_articles

Part of the Jurisprudence Commons, Legal Profession Commons, and the Legal Writing and Research Commons

How does access to this work benefit you? Let us know!

\section{Original Citation}

David R. Barnhizer, Truth or Consequences in Legal Scholarship?, 33 Hofstra Law Review 1203 (2005)

This Article is brought to you for free and open access by the Faculty Scholarship at EngagedScholarship@CSU. It has been accepted for inclusion in Law Faculty Articles and Essays by an authorized administrator of EngagedScholarship@CSU. For more information, please contact research.services@law.csuohio.edu. 


\section{HEINONLINE}

Citation: 33 Hofstra L. Rev. 1203 2004-2005

Content downloaded/printed from

HeinOnline (http://heinonline.org)

Thu Oct 4 17:15:02 2012

-- Your use of this HeinOnline PDF indicates your acceptance of HeinOnline's Terms and Conditions of the license agreement available at http://heinonline.org/HOL/License

-- The search text of this PDF is generated from uncorrected OCR text.

-- To obtain permission to use this article beyond the scope of your HeinOnline license, please use:

https://www.copyright.com/ccc/basicSearch.do?

\&operation $=$ go\&search Type $=0$

\&lastSearch $=$ simple\&all $=$ on\&titleOrStdNo $=0091-4029$ 


\title{
TRUTH OR CONSEQUENCES IN LEGAL SCHOLARSHIP?
}

\author{
David Barnhizer*
}

I. INTRODUCTION

II. LAW, LEGAL TRUTH AND LEGAL SCHOLARS

III. AN EXAMPLE OF THE DEGRADATION OF TRUTH AND TRUTH-

SEEKING.

IV. POSTMODERNISM AND "TRUTH-VALUE"

V. THE DEgRadATION OF THE IDEALS OF TRUTH AND TRUTH-

SEEKING

VI. CONCLUSION: RESISTING THE DEgRADATION OF THE IDEAL .... 1237

\begin{abstract}
There has been an erosion of the ideal of truth as a guiding force for what we do. This includes a dishonoring of the tradition of the truthseeking function of scholars. ${ }^{1}$ For the university-based intellectual, including legal scholars, the problem with commitments to ends other than truth-seeking is that once we accept a mission distinct from the pursuit of truth and honest discourse, most of the remaining options are suspect-including falseness, hypocrisy, self-deception, subordination of self to a collective, profit, dogmatism, devotion to tradition, and propaganda.

* Professor of Law, Cleveland State University.

1. Donald Kennedy, former president of Stanford University, laments in Academic Duty that: "The list of scientists publicly tainted by charges that either they or their colleagues have published falsified data reads like a Who's Who of biomedical research." DONALD KENNEDY, ACADEMIC DUTY 211 (1999). He observes: "Today ... the public would react to such a revelation [of academic Charles Van Doren's game-show fraud] both more calmly and more cynically. The change illustrates just how serious a threat to the public's confidence in the value of scholarship is the belief that its pursuit is marred by personal interest, greed, or dishonesty. Many factors are involved in higher education's fall from grace in the past decade. But surely one of the most troubling, especially for the sciences, is the issue of 'research misconduct."' $I d$. at 210.
\end{abstract}


Although what we intend by the idea of truth-legal, scientific, political and otherwise-is obviously subtle, wide-ranging, functionally disparate and perhaps impossible to make entirely concrete, this essay concentrates on the complex and beleaguered phenomena of truth and truth-seeking within academia and the noncumulative disciplines of which law is a part. ${ }^{2}$ This focus is chosen because of the belief that a society without commitment to the ideal of truth with integrity and honesty (even if not entirely real or provable) is not a community but only a collection of people seeking to take advantage of each other while never being able to trust the validity of anyone or anything. ${ }^{3}$ A society without the ability to negotiate reliable terms of what will be considered "true" and thus authoritative is one in which promises are meaningless, nothing is reliable, and betrayal is a predictable and even inevitable condition of relationships. ${ }^{4}$ Western societies grounded on the Rule of Law cannot afford to surrender such a basic principle without devolving into a system operating on increasingly prevalent use of force and Machiavellian machinations by fragmented but powerful political cliques.

2. Crane Brinton, Ideas and Men: The Story of Western Thought 9, 13 (2d ed. 1963), describes noncumulative knowledge as the knowledge of philosophy, morality, ethics and the like, which we can debate but not prove by use of empirical methods. He compares this with cumulative knowledge in the domain of science to which we can add greater certainty and specificity. Law is a form of noncumulative knowledge.

3. Martin Buber argues:

In our age, in which the true meaning of every word is encompassed by delusion and falsehood, and the original intention of the human glance is stifled by tenacious mistrust, it is of decisive importance to find again the genuineness of speech and existence as We.... Man will not persist in existence if he does not learn anew to persist in it as a genuine We.

MARTIN BUBER, THE KNOWLEDGE OF MAN 108 (Maurice Friedman \& Ronald Gregor Smith trans., Maurice Friedman ed., 1965). Dahl suggests much the same as a natural behavioral phenomenon of how collectives operate: "Organizations thereby strengthen both solidarity and division, cohesion and conflict; they reinforce solidarity among members and conflicts with nonmembers. Because associations help to fragment the concerns of citizens, interests that many citizens might sharelatent ones perhaps-may be slighted." ROBERT A. DAHL, DILEMMAS OF PLURALIST DEMOCRACY: AUTONOMY VS. CONTROL 44 (1982).

4. Brinton speaks of Nietzsche's advice about the necessity of recognizing the function of untruth as a condition of life and the importance of false beliefs and fictions as life preserving and system preserving. See BRINTON, supra note 2 , at 401 . Brinton reminds us that:

What does move men in society, and keeps them together in society, says Pareto, is the residues. These have extraordinarily little intellectual in them, though they are usually put in logical form. They are expressions of relatively permanent, abiding sentiments in men, expressions that usually have to be separated from the part that is actually a derivation, which latter may change greatly and even quickly.

Id. at 406. 
Camus warns of the distortion that occurs when individuals engaging in the struggle to achieve what they think to be social justice simultaneously try to be clear-thinking scholars. ${ }^{5}$ Consider his poignant observation in the context of the creativity of the artist and the need to keep sufficient distance from the heated conditions of society in order to retain a clear perspective. He writes:

[I]t is not possible to be a militant in one's spare time. And so the artist of today becomes unreal if he remains in his ivory tower or sterilized if he spends his time galloping around the political arena. Yet between the two lies the arduous way of true art. It seems to me that the writer must be fully aware of the dramas of his time and that he must take sides every time he can or knows how to do so. But he must also maintain or resume from time to time a certain distance in relation to our history. ${ }^{6}$

We have lost the distance and are increasingly consumed by ideology and the narrowness of political perspective. A result is that much of what is said in noncumulative academic disciplines such as law is suspect.

\section{INTRODUCTION}

This analysis begins with the assertion that there is a fundamental incompatibility between the pursuit of truth and the pursuit of consequences. The danger is that it is extraordinarily easy to mistake belief for validity, and this risk expands greatly when someone becomes part of a politically-driven identity collective. ${ }^{7}$ The situation is

5. See Albert Camus, The Wager of Our Generation, in RESISTANCE, REBELLION, AND DEATH 237, 238-39 (Justin O'Brien trans., 1960).

6. Id. at 238. Jung warns:

Rational argument can be conducted with some prospect of success only so long as the emotionality of a given situation does not exceed a certain critical degree. If the affective temperature rises above this level, the possibility of reason's having any effect ceases and its place is taken by slogans and chimerical wish-fantasies.

CARL GuSTAV JUNG, THE UNDISCOVERED SELF 2 (Routledge ed., 1958).

7. See Robert Paul Wolff, The Poverty of Liberalism 17 (1968); see also Fred Hechinger, About Education: Humanities Peer Review is Faulted N.Y. TIMES, Sept. 30, 1986, at C1; ANTHONy J. Diekema, ACADEMIC FReEdom and Christian Scholarship 45-46 (2000). Diekema remarks:

Arthur Koestler ... observes that "professionals with a vested interest in tradition and in the monopoly of learning" always tend to block the development of new concepts. "Innovation is a twofold threat to academic mediocrities," he writes. "It endangers their oracular authority, and it evokes a deeper fear that their whole laboriously constructed intellectual edifice might collapse."

Id. at 45 . He continues: 
exacerbated when collectives committed to common agendas; identity preferences; and political transformation in ways that advance their members' interests in what is often a zero-sum game, gain control of any system. This includes the academic system that over the last several decades has experienced the struggle for equitable treatment of women and historically disadvantaged minorities.

Part of our difficulty is that the search for distributional and corrective justice is inevitably political and directed toward gaining the power required to achieve desired ends. Organized strategies in service of these power-directed agendas have been brought into the heart of the university and university law schools. As admirable as I feel the social reforms have been, it is undeniable that the independent search for truth is inescapably diluted and diverted as part of the seeking of the particular political consequences desired by the collectives that make up the various movements. ${ }^{8}$ To the extent truths are even thought relevant in the context of the resulting political process they are assumed rather than assessed, and the goal is no longer insight and understanding but achieving preferred political outcomes. ${ }^{9}$

The irony is that as the reformist critics of power have been successful in taking over the university institution they have become the system and in doing so, have engaged in many of the same flawed

[S]peaking to the negative aspects of the historic relationship between academic freedom and tenure, John Silber (1973) writes, "Infringement by tenured professors of the rights of non-tenured faculty to develop their intellectual interests according to their own professional judgment . . . represents by far the most serious and most frequent violation of academic freedom in our colleges and universities."

Id. at 46 (omission in original).

8. "[John Stuart] Mill was a pioneer in seeing, with the growth of social egalitarianism and mass culture, the shadow of 'an oppressive yoke of uniformity in opinion and practice." Max Lerner, Preface to JOHN STUART MILL, On Liberty, in EsSEnTIAL WORKS OF JOHN STUART MILL 249, 251 (Max Lerner ed., Bantam Matrix 1961). Compare this with Jung's point that

[T]he gift of reason and critical reflection is not one of man's outstanding peculiarities, and even where it exists it proves to be wavering and inconstant, the more so, as a rule, the bigger the political groups are. The mass crushes out the insight and reflection that are still possible with the individual, and this necessarily leads to doctrinaire and authoritarian tyranny....

JUNG, supra note 6 , at 2 .

9. DAHL, supra note 3, at 44. Dahl states:

Organizations ... are not mere relay stations that receive and send signals from their members about their interests. Organizations amplify the signals and generate new ones. Often they sharpen particularistic demands at the expense of broader needs, and shortrun against long-run needs.... Leaders therefore play down potential cleavages and conflicts among their own members and exaggerate the salience of conflicts with outsiders.

Id. 
behaviors. The formerly external critics who perceived themselves as "speaking truth to power" now find it impossible to criticize the institution because they are now in control of the levers of power. Many have sorted themselves out into organized cadres made up of impassioned advocates dedicated to the advancement of personal causes and the suppression of that which is inconsistent with their views. They have become dependent on the extremely comfortable sinecures provided by their professional positions and have sought to redesign the landscape into one consistent with their needs and desires. ${ }^{10}$

At the center of my concern is the distinction between the intellectual, who traditionally has been a prophetic critic of power, and the careful scholar who has long been thought to be at the heart of the university's mission in both teaching and research. Along with this distinction between intellectual and scholar is that between the aggressive advocate-activist and the reflective independent thinker seeking the deepest understanding, whatever its implications. Each has an important role but we delude ourselves when we fail to understand that the roles are distinct and often incompatible. Academic freedom and the strong commitment to truth-seeking have suffered as aggressive activists have flooded into the university professoriate over the past thirty years.

\section{LAW, LEGAL TRUTH AND LEGAL SCHOLARS}

Law and the nature and function of legal truth have their own compelling logic. Part of the task of understanding and serving that logic involves the responsibilities of scholars and judges because, within the boundaries of a rich system of political power that creates and allocates rights and duties, it is judges and scholars who seek to develop and apply different kinds and degrees of truth and do so in service of distinct though often related goals. ${ }^{11}$ When it comes to being specific about the

10. Diggins concludes: "Today the Left's life-support system is the university, which has produced a 'new class' credentialed with advanced degrees and enjoying elite status, what Thorstein Veblen-whose Higher Learning in America bears the subtitle 'A Study in Total Depravity'would probably have called 'The Leisure of the Theory Class."' JOHN PATRICK Diggins, THE RISE AND FALL OF THE AMERICAN LEFT 290 (1973).

11. A substantial element of my work has focused on these issues. See, e.g., David Bamhizer, Freedom to Do What? Institutional Neutrality, Academic Freedom, and Academic Responsibility, 43 J. Legal Educ. 346 (1993); David Barnhizer, The Justice Mission of American Law Schools, 40 CleV. ST. L. REV. 285 (1992); David Bamhizer, The Purposes of the University in the First Quarter of the Twenty-First Century, 22 SETON HALL L. REV. 1124 (1992); David Bamhizer, The University Ideal and Clinical Legal Education, 35 N.Y.L. SCH. L. REV. 87 (1990); David Barnhizer, The Revolution in American Law Schools, 37 CLEV. ST. L. REV. 227 (1989); David Bamhizer, The 
interactions among truth, legal truth, power and knowledge, legal scholars face a unique challenge. ${ }^{12}$ Contrary to Christopher Langdell, who proclaimed proudly that law was a science and legal scholars were the scientists of law, law and legal scholarship are complex and fluid admixtures of often incompatible data, values, principles, goals and opinions that defy neat definition. ${ }^{13}$ These diverse elements are inherently incompressible in their most important dimensions.

Given the diversity of form, subject matter, method and function necessarily served by legal "truth," it is impossible to achieve any ultimate or static legal truth of independent character. Felix Cohen once wrote about the ephemeral nature of legal knowledge with what I hope was a strong sense of humor when he described the European jurist Von Jhering as dreaming he had died and found himself in a "special heaven reserved for the theoreticians of the law."14 All new entrants to heaven

University Ideal and the American Law School, 42 RUTGERS L. REV. 109 (1989); David Bamhizer, Prophets, Priests, and Power Blockers: Three Fundamental Roles of Judges and Legal Scholars in America, 50 U. PITT. L. REV. 127 (1988).

12. See James Bryant CoNANT, Two Modes of Thought 44 (1964). Langdell argued: "Law, considered as a science, consists of certain principles or doctrines. To have such a mastery of these as to be able to apply them with constant facility and certainty to the ever-tangled skein ... should be the business of every earnest student of law." C. C. LANGDELL, A SELECTION OF CASES ON THE LAW OF CONTRACTS, at vi (Legal Classics Library spec. ed., Leslie B. Adams, Jr. 1983).

13. See Conant, Two Modes of Thought, supra note 12. John Finnis argues that law is a "cultural object, constructed or posited by creative human decision, [and] is an instrument which we adopt for a moral purpose, and which we adopt because we have no other way of agreeing amongst ourselves over significant spans of time about precisely how to pursue our moral project well." John Finnis, Natural Law and Legal Reasoning, 38 CLEV. ST, L. REV, 1, 6 (1990) [hereinafter Finnis, Natural Law]; see generally JOHN FINNIS, NATURAL LAW AND NATURAL RIGHTS (1980). He further describes law as providing "algorithm[s] for deciding as many questions as possible .... As far as it can, the law seeks to provide sources of reasoning - statutes and statute-based rules, common law rules, and customs - capable of ranking (commensurating) alternative dispute resolutions as right or wrong, and thus better or worse." Finnis, Natural Law, supra, at 6-7. But the problem is that there is no single value capable of automatically trumping all others, and this is why we lack ability to gain any consensus on truth and why we are advocates as well as scholars in the law schools and the other noncumulative disciplines. Sunstein concludes: "[W]e value things, events, and relationships in ways that are not reducible to some larger and more encompassing value. The second claim is that human goods are not commensurable. By this I mean that such goods are not assessed along a single metric." CASS R. SUNSTEIN, FREE MARKETS AND SOCIAL JUSTICE 70 (1997). He goes on to conclude that "efforts to insist on a single kind of valuation and to make goods commensurable, while designed to aid in human reasoning, may actually make such reasoning inferior to what it is when it is working well." Id.

14. Felix S. Cohen, Transcendental Nonsense and the Functional Approach, 35 CoLUM. L. REV. 809, 809 (1935). Another legal scholar highlights the synthesizing and inherently interdisciplinary character of law: "Law is a scavenger. It grows by feeding on ideas from outside, not by inventing new ones of its own." E. Donald Elliott, The Evolutionary Tradition in Jurisprudence, 85 COLUM. L. REv. 38, 38 (1985). Edward Levi has pointed out the function of 
were required to drink the "draught which induced forgetfulness" so they would no longer be encumbered with earthly knowledge. The draught proved superfluous for jurists. It turned out "[t]hey had nothing to forget" because they actually knew nothing. ${ }^{15}$

This condition of ambiguity and dynamic adaptation to the needs of specific cultures at specific moments exists because virtually all of the decisions reached by judges as well as the analytical framework within which legal scholars work are part of a bounded activity. They reflect positivist hypotheses by scholars regarding whether what judges have said individually and collectively are valid interpretations of the language chosen by legislators or other judges in the form of authoritative law or whether the actions of executive agents seeking to implement the law are within its ambit. When a scholar looks at legal "truth" that individual is asking in many instances whether the claimed position is consistent with the particular hypothesis that is argued to be applicable to the specific legal micro-universe being considered. Truth is determined in a context of consistency, language, precedent, and underlying systemic grant of authority rather than in reference to some ultimate Lex or system of natural law permeating the very fabric of our existence. ${ }^{16}$

This idea of working within bounded limits was suggested by Francis Bacon when he warned that judges should restrict themselves to dealing with the "immediate cause" involved in the disputes before them or be lost in the infinity of possibilities. ${ }^{17}$ For legal scholars and judges

ambiguity in the dynamic process of the Common Law as well as the necessity of fictions and control of both the pace and obviousness of change in legal doctrine. Edward Levi remarks:

The categories used in the legal process must be left ambiguous in order to permit the infusion of new ideas.... Furthermore, agreement on any other basis would be impossible. In this manner the laws come to express the ideas of the community and even when written in general terms, in statute or constitution, are molded for the specific case.

EDWARD H. LEVI, AN INTRODUCTION TO LEGAL REASONING 4 (1949).

15. Cohen, supra note 14 , at 809 .

16. Berman states:

It is widely accepted in our law schools that law is essentially something that is made by political authorities, including legislators, judges, and administrators, to effectuate their policies; that law is essentially a means of social engineering; that law is essentially a pragmatic device, an instrument, used by those in power to accomplish their will. Of course law is all that. But it is not solely that-it is not essentially that. What is omitted from the prevailing view is a belief that law is rooted in something bigger than the people who hand it down - that law is rooted in history and in the moral order of the universe.

Harold J. Berman, The Crisis of Legal Education in America, 26 B.C. L. REV. 347, 348 (1985).

17. FRANCIS BACON, THE ELEMENTS OF THE COMMON LAWES OF ENGLAND: THE MAXIMS OF THE LAW, Regula I (1630). Bacon observes that judicial decisions are appropriately limited to the 
truth is an important concern but it is a truth of comparison, consistency, precedential authority and linguistic interpretation inside a mostly closed system rather than inquiry into ultimate truths wherever they might lead. Both scholar and judge might seek an incremental extension of their particular truths in attempting to determine the right way a dispute should be resolved, but even then they are working through comparisons within a closed system and for purposes different from those of scientists, philosophers, or even religious believers. ${ }^{18}$

In asserting the vital role of the ideals of truth and truth-seeking as part of the spirit of trust and authenticity which binds together and sustains political communities, it must be admitted that many in the political/academic cabals who have organized themselves into collectives centered on issues that lie at the heart of our most volatile social conflicts will bristle at the suggestion that they must follow the rules set out by generations of the same "kind" of people they consider responsible for their oppression. I want to make a distinction at this point between academics and scholars. As I use the term, an academic is anyone holding a teaching/research position in a university or college. Many of the new academics will be intellectuals in the activist or critical sense in which they are primarily committed to achieving what they consider to be just political consequences. Others will simply be academic bureaucrats and place-takers. The problem is that a scholar will almost certainly be an academic, but someone holding an academic position will frequently not be a scholar and, in fact, may resent or feel threatened by real scholars.

Here it is not surprising that academics and activists who feel that members of their identity group have suffered from generations of unjust

\footnotetext{
"immediate cause" because: "It were infinite for the law to judge the causes of causes, and their impulsions one of another: therefore it contenteth itself with the immediate cause; and judgeth of acts by that, without looking to any further degree." Id. Similarly, Levi explains a key element of the system in his admission: "The law forum is the most explicit demonstration of the mechanism required for a moving classification system. The folklore of law may choose to ignore the imperfections in legal reasoning, but the law forum itself has taken care of them." LEVI, supra note 14 , at 4 .

18. The necessity of not straying too far beyond the closed system into an endless and twisting universe of abstraction is suggested by Boorstin's warning:

[T] he mystery-of law in modern society. How retain any belief in the immanence of law, in its superiority to our individual, temporary needs, after we have adopted a wholehearted modern belief in its instrumentality? How continue to believe that something about our law is changeless after we have discovered that it may be infinitely plastic? How believe that in some sense the basic laws of society are given us by God, after we have become convinced that we have given them to ourselves?

Daniel J. BOORSTIN, THE DECline OF RADICALISM: REFLECTIONS ON AMERICA TODAY 75-76 (1963).
} 
discrimination and exclusion ask, Truth? Where was your reverent thirst for Truth during the generations in which my group was being repressed? Don't tell me of your Truth-give us what we are due and then we can talk about Truth. As an activist who has spent his life in civil rights and other public interest activities, I share much of this indignation and the commitment to rectify injustice. ${ }^{19}$ There has been extreme discrimination against racial minorities and women and this is part of our system's illegitimate hypocrisy, including in law schools and universities. Such discrimination has been addressed in some areas but remains in many fields of activity where opportunities are restricted through subtle but still unjust means. ${ }^{20}$

Although I share the goals of equality and opportunity and have spent a considerable part of my life as an activist there is no question that the presence, politics and perspectives of activist, intellectuals have altered the environments of teaching and scholarship. Simply because some things are necessary does not mean all agendas and strategies are acceptable. Nor does it mean that those who seek revolutionary reform are themselves free of the tendency to abuse power and suppress those with whom they disagree. The tendency to abuse power transcends race or gender. We are all corrupted by its possession and systems can mute the corrupting effects of power only by creating institutions that balance power and allow its mitigation. The demography of American academia now consists of many who see themselves as what Cynthia Ozick calls "public intellectuals." As intellectuals they feel responsible for achieving system change on behalf of the interest group with which they most closely identify. They are not dispassionate scholars committed to careful and meticulous research and analysis. ${ }^{21}$

19. Maxine Greene suggests why so many of us accept the activist responsibility. She describes the existentialist belief that we create ourselves through our chosen actions:

For the existentialist, the self is devoid of character or coloration before action is undertaken. When the individual begins devising projects and purposes, he begins creating an identity. No outside factor or force, no science or set of rules or moral law, can make decisions for him. The only significant choices are those that involve him totally and project his existence into a future still unknown. The only meaningful choices are those for which he takes full responsibility.

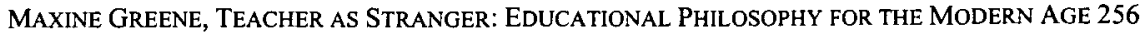
(1973).

20. See Gary Younge, Culture War Casualties: Polarisation in US Politics Reflects the Huge Rift that Has Emerged Over Individual Lifestyle and Moral Values, GUARDIAN (London), Apr. 5 , 2004, available at http://www.guardian.co.uk/comment/story/0,1185691,00.html (discussing gay marriage and civil unions).

21. See, e.g., CYNTHIA OzICK, QUARREL \& QUANDARY: ESSAYS BY CYNTHIA OZICK 120-26 (2000) 
To some degree the activist scholar combines the role of the "public intellectual" with that of the more removed scholar. The roles are at best in an uneasy balance and often in conflict. Although they overlap in many instances, the roles of the intellectual and that of the scholar are not identical. Richard Posner has become known popularly for his writing on the "public intellectual,"22 but the more relevant meaning of that term is one that was used earlier by Cynthia Ozick. Ozick draws a distinction between the public intellectual and the "other kind" by arguing: "Public intellectuals know that history is where we swim, that we are in it, that we can't see over or around it, that it is our ineluctable task to grapple with it."23

This distinction is important because we have experienced a blurring of the lines over the last thirty years between the roles of activist intellectuals and scholars. This shift has occurred because activists have flooded into academia in large numbers and have used their academic base as a forum to achieve political agendas. The intellectual, as a historical and cultural phenomenon, has traditionally been located on the outside of institutional structures critiquing what is seen as wrong or sinful in the name of God or justice. ${ }^{24}$ The role of the intellectual has even been compared to that of the prophet as critic of entrenched power. ${ }^{25}$ In terms of the impacts on the search for truth

22. See generally Richard A. Posner, Public InTellectuals: A Study of DeCline (2001).

23. OzICK, supra note 21 , at 123 . She argues: "Thinkers ... do not simply respond to existing conditions; in the buzz, confusion, and chaos of the Zeitgeist they strive to sort out-to formulatethe cognitive and historic patterns that give rise to public issues." $I$ d.

24. Hoffer argues: "The intellectual as a champion of the masses is a relatively recent phenomenon." ERIC HOFFER, THE ORDEAL OF CHANGE 43 (1952). Hoffer continues:

[I]n the eighth century B.C., owing to an obscure combination of circumstances [the

Hebrews] began to develop a most strange deviation. Side by side with the traditional men of words-priests, counselors, soothsayers, scribes-there emerged a series of extraordinary men who pitted themselves against the ruling elite and the prevailing social order. These men, the prophets, were in many ways the prototype of the modern militant intellectual. Id. at 44 .

25. Hoffer argues: "Many of the characteristic attitudes of the modern intellectual-his tendency to see any group he identifies himself with as a chosen people, and any truth he embraces as the one and only truth; the envisioning of a millennial society on earth-are clearly discerned in the prophets." Id. at 45 . On the themes of the nature, function or origin of intellectuals as a distinct class, see Michael Walzer, THe COMPaNy of Critics: Social Criticism and Political COMMITMENT IN THE TWENTIETH CENTURY (1988); Christopher LASCH, THE NEW RADICALISM IN AMERICA [1889-1963]: THE INTELLECTUAL AS A SOCIAL TYPE (1965). See also François FURET, THE PASSING OF AN ILLUSION: THE IDEA OF COMMUNISM IN THE TWENTIETH CENTURY 482 (Deborah Furet trans., 1999) (reminding us of how intellectuals may be cowed by power in his observation that "The notion of an anti-Soviet, Soviet intellectual was not only unknown but hardly 
through balanced inquiry, rigorous method, and open discourse, it is not a minor event that the historically external base of the critical intellectual has been brought into the university, both modifying and supplanting the tradition of the scholar. The newly entrenched intellectuals see their mission as the voicing of political challenges to a system they consider biased and repressive. ${ }^{26}$

To the extent that the emerging activist collectives operate strategically, not only within their own universe of discourse but in seeking to permeate the culture of all discourse related to their claimed intellectual and political "territory," they become intellectually repressive. ${ }^{27}$ I believe this is what John Silber feared when he voiced his concerns about what he called "epistemopathologies." 28 The issue begins with feminist, critical race, political economy, religious and genderoriented scholarship, not as topics of appropriate scholarly inquiry-

conceivable. ... The decimation of the Soviet intelligentsia during the 1930 s went all but unnoticed in Western Europe. The Right ignored it, for lack of interest; the Left, for lack of perception").

26. Ironically this mirrors Duncan Kennedy's criticisms of traditional law faculties whose hiring patterns essentially cloned themselves. Now this same tactic is being used to expand the numbers of special interest faculty. See Duncan Kennedy, Legal Education and the Reproduction of Hierarchy, 32 J. LEGAL EDUC. 591 (1982); see also Catharine W. Hantzis, Kingsfield and Kennedy: Reappraising the Male Models of Law School Teaching, 38 J. LEGAL EDUC. 155 (1988).

27. Dahl points out the dangers of collective activity:

[B]y emphasizing aspects of the self that are enhanced by organizational or segmental gains, organizational pluralism helps to produce in political actors a set of perceptions and beliefs, even a persistent political culture, in which the absence of a common, public, or widely shared set of interests is a self-fulfilling prophecy. I and my "interests" become attached to my social segment and my organizations; leaders in my organizations in turn seek to increase the strength and salience of my attachments; my public interest becomes identical in my mind with my segmental interest; since what is true of me is true of others, we all passively or actively support the organizational fight on behalf of our particularistic interests; finally, as levels of distrust rise and effective communication declines, the "rational" pursuit by each of us of our particularistic self-interest may lead to mutually damaging outcomes.

DAHL, supra note 3, at 44-45.

28. Alice Dembner, Silber Says New Theories Can Put Limit on Freedom, Boston GLOBE, Nov. 30, 1993, at Metro/Region 1. Silber had published remarks that Boston University had "remained highly resistant to political correctness and ideological fads." Id. The areas resisted, Silber said, included "critical legal studies, revisionist history, Afro-centrism, radical feminism, [and] multiculturalism." Id. Silber had stated that: "certain versions of radical feminism, multiculturalism, and other intellectual theories should be resisted because they are "inhospitable to free intellectual inquiry." $I d$. The report added:

Marxism was not included in Silber's earlier remarks as an area that had been "resisted." Those mentioned in the April 15 report to [Boston University] trustees were critical legal studies, revisionist history, Afro-centrism, radical feminism, multiculturalism, the Frankfurt School of Critical Theory, structuralism and deconstructionism, dance therapy, gay and lesbian liberation and animal liberation.

Id.; see also Alice Dembner, Silber Defends Record, Calls Faculty Leader Liar, Boston GLoBE, Dec. 1, 1993, at Metro/Region 1. 
because they obviously are-but as political movements with strong commitments to advancing specific strategic agendas, which they also are. This in no way is intended to say these movements are not needed, but recognizes that they are political activities which are at the center of the offensive and defensive.struggle in which the university now finds itself.

Harvard's Lawrence Summers experienced significant criticisms for suggesting that men and women may have generally distinct innate capacities in some fields of activity. ${ }^{29}$ Compare Summers's points with the following conclusions offered by Helen Fisher in The First Sex: The Natural Talents of Women and How They Are Changing the World.$^{30}$ Fisher argues: "I believe there are subtle differences in the ways that men and women, on average, organize their thoughts-variations that appear to stem from differences in brain structure. ... Feminine thinking is even affecting our basic beliefs about justice, health, charity, leisure, intimacy, romance, and family." ${ }^{31}$ Fisher continues:

[W] ]omen, on average, take a broader perspective than men do-on any issue. Women think contextually, holistically. They also display more mental flexibility, apply more intuitive and imaginative judgments, and have a greater tendency to plan long term-other aspects of their contextual perspective.... [W]omen's broad, contextual, holistic way of seeing will pervade every aspect of twenty-first-century economic and social life. ${ }^{32}$

This argues for a material difference between how men and women think, collaborate and act. It is difficult to avoid concluding that Fisher feels the innate characteristics she attributes to women are preferable and superior to those of men. Yet even though I feel it is fair to question many of Fisher's points in terms of their validity, I have heard no one attacking her for her broad and sweeping claims to superior qualities for her gender.

What is being done to Lawrence Summers reflects the increasingly absolute form of reverse sexism and intellectually dishonest propaganda that has afflicted the American university and society generally. It really is an uneven and unfair battle, and the one-sidedness has gone far enough. Lawrence Summers's comments may well have been unwise as

29. Harvey Mansfield, Fear and Intimidation at Harvard: What Do Academic Women Want?, WKIY. STANDARD, Mar. 7, 2005, at 10, 10-11.

30. Helen E. Fisher, THE First SEX: THE NatUral TALENTS OF WOMEN and How THEY ARE CHANGING THE WORLD (1999).

31. Id. at 4 .

32. Id. 
a political statement by a president of one of the most prestigious institutions in the world. ${ }^{33}$ Certainly his presidency renders him more of an academic politician than a scholar, and he should understand the political implications of what he says. Nor were such differences as he mentioned in terms of the possible inherent ability distinctions between women and men among his areas of scholarly expertise. An actual reading of the entire transcript of his remarks, however, clearly reveals an individual seeking to offer possible interpretations of a complex situation in order to generate discourse and inquiry. ${ }^{34}$ Summers readily admitted during his presentation that some of the points he made are uncertain and that his remarks reflected a degree of uncertainty and speculation. ${ }^{35} \mathrm{He}$ responded reasonably to inquiries from the floor, including those from women who somehow were able to remain in the room and engaged in the scholarly endeavor of actually thinking through the meaning and intent of his remarks and challenging them as inappropriate, unclear or inaccurate. ${ }^{36}$ Summers may have made a political mistake in speaking at all, but he and most of the others present engaged in inquiry with the give and take of real communication. I challenge anyone who actually reads the transcript to walk away with the feeling that Summers is a sexist ideologue.

The reaction by a figure such as Nancy Hopkins, who claimed she was being made ill by his remarks to the point she had to flee the room was so extreme that the only reasonable interpretations are that she: (a) grabbed for the momentary celebrity and prominence by running to the media as fast as possible in order to be the first with the story; (b) is seeking to orchestrate a campaign of language control and intimidation aimed at people who dare question any of her cherished values and biases; or (c) is extremely allergic to any statements that do not fit her worldview. Personally, given her obvious media savvy and organizational ability to keep the pot stirred and Summers under fire for a considerable period, my guess is that she is a highly skilled

33. Summers's full presentation can be found on the Harvard University website, and numerous other sites. Readers should review the entire presentation before hanging Summers. See Lawrence H. Summers, Remarks at NBER Conference on Diversifying the Science \& Engineering Workforce (Jan. 14, 2005), available at http://www.president.harvard.edu/speeches/2005/nber.html. Summers, of course, has abjectly apologized if he offended or insulted anyone. Annie Schleicher, Harvard President's Comments Spark Debate About Gender (Jan. 24, 2005), at http://www.pbs.org/newshour/extra/features/jan-june05/harvard_1-24.html.

34. See Summers, supra note 33.

35. Id.

36. Id. 
Machiavellian deserving of both fear and respect. ${ }^{37}$ Her record on this issue suggests that Hopkins came to the session prepared to politicize it to her advantage and in service of her clear political agenda. Certainly, if anything resembling the requirement to provide supportable and verifiable data for one's public statements about an important issue was applied to Hopkins's earlier study in which she found rampant discrimination against women faculty at MIT without being able or willing to provide hard evidence of actual discrimination, that study would be relegated to the trash bin. ${ }^{38}$

Summers is without question a controversial figure and was seen as such by the activist and public interest communities even before he arrived at Harvard as its president. In one of my own fields of international environmental and development activism, Summers was considered an uncharitable figure due to a memo he wrote while Chief Economist at the World Bank that contradicted some of the core beliefs and arguments of the non-governmental organizations working and politicking in that domain. ${ }^{39}$ Shortly after arriving at Harvard, he

37. Deborah Tannen's analysis seems to fit Hopkins's behavior perfectly. See DEBORAH TANNEN, THE ARgument CULturE: MOVING FROM DEBATE TO DiAlOGUE 5-8 (1998) (seeking to understand what had happened to evidence-based discourse). Tannen states:

The answer crystallized when I put the question to a writer who I felt had misrepresented my work: "Why do you need to make others wrong for you to be right?" Her response: "It's an argument?".... When you're having an argument with someone, your goal is not to listen and understand. Instead, you use every tactic you can think of-including distorting what your opponent just said-in order to win the argument.

Id. at 5. She continued:

In the argument culture, criticism, attack, or opposition are the predominant if not the only ways of responding to people or ideas. I use the phrase "culture of critique" to capture this aspect. "Critique" in this sense is not a general term for analysis or interpretation but rather a synonym for criticism.

Id. at 7. I suggest that Hopkins sees nothing wrong with her own behavior for much the same reason Tannen describes: It's a war, war is hell, there are victims, and you do whatever it takes to win.

38. Kathryn Jean Lopez, Feminist Mythology: The New Age MIT and Its Chorus, NAT'L REv. ONLINE, Apr. 10, 2001, at http://www.nationalreview.com/nr_comment/Nr_comment041001b.shtml. Lopez argues:

The MIT mea-culpa report is a classic product of a New Age MIT, with little more than feelings as evidence of discrimination. Gender discrimination is "subtle but pervasive," the report concludes, "and stems largely from unconscious ways of thinking that have been socialized into all of us, men and women alike." MIT's Committee on the Status of Women, for instance, reported, "a common finding for most senior women faculty was that the women were "invisible." The study found that, "Many tenured women faculty feel marginalized and excluded from a significant role in their department." If MIT did collect any data about this "universal problem," the school has refused to release it, claiming it was "confidential."

Id.

39. See U.S. Treasury Secretary-to-Be Dumps on World, Global SitUATION ReP., May 25, 1999, at http://www.gsreport.com/articles/art000171.html. The GSR relates: 
managed to "diss" Cornel West by apparently not liking the way he rapped and by not calling to inquire after his health when he did not feel well. ${ }^{40}$ After seeking to punish Summers in the press and generally coming off as a petulant adolescent, West took his show off to Princeton where perhaps his tunes were better appreciated by authority figures. ${ }^{41}$

Notwithstanding the savaging of Summers by West and Hopkins, the most effective constraints on real intellectual freedom and quality of scholarship tend to be implicit rather than overt. ${ }^{42}$ Academics are not brave by nature and are easily intimidated. Sexism, racism, ethnocentrism or any of the seemingly innumerable phobias that have come into vogue as condemnatory strategies of repression are enough to silence virtually any scholar or intellectual. Diekema, for example, suggests that there is a "chilling effect" that creates a climate in which scholars steer clear of controversial or unpopular topics, arguing: "Selfcensorship is often a result of the "chilling effect," and he goes on to emphasize that it "is not the iron fist of repression but the velvet glove of seduction that is the real problem.,"43 Diekema concludes that: "Faculty simply do not always say what they believe, or what they know to be true, because they don't want to deal with what may be the resulting hassle-peer alienation, negative student opinions, or the ire of a

Prior to coming to Treasury, Summers served as chief economist for the World Bank. In that post, back in December 1991, he wrote an internal memo regarding how the toxic wastes of the industrial world should be dumped on the less developed world. The memo was leaked to environmental activist Jim Vallette, then with Greenpeace, who made sure it went public. The memo is a chilling example of a mindset that may be common, if not always visible, in the halls of power.

Id. My point is that the public interest community was not favorably disposed toward Summers long before he was tapped to be Harvard's president.

40. See John H. McWhorter, The Mau-Mauing at Harvard, CITY J. (New York), Spring 2002, available at http://www.city-journal.org/htmV/12_2_the_mau_mauing.html (criticizing West's behavior).

41. Compare id., with Faculty Profile of Professor Cornel West, at http://www.princeton.edu/ aasprog/faculty_professors.html (last visited July 10, 2005) (showing that after being "disrespected" and "dishonored," and after having been courted by Princeton, West threatened to "bolt" to Princeton, which he eventually did).

42. See, e.g., ANNE Fausto-STERling, Myths of Gender: Biological THEORIEs ABout WOMEN AND MEN 203 (1985). She suggests:

The major sociobiological theorists have expressed astonishment, outrage, and genuine anger at the force of expressly political attacks on their work. They had, they pointed out, not the least intention of working against social change. . . For apparently as these scientists developed their theories they never questioned their stance as politically neutral investigators interested only in empirical truth. Whatever science finds, after all, must be openly confronted. The truth is the truth, and if it's unpleasant so be it. Let's not kill the messenger because he bears sorrowfil tidings.

Id.

43. DIEKEMA, supra note 7 , at 34 . 
constituent community." 44 One or two episodes such as the one Lawrence Summers has experienced as the president of Harvard are all that is required to warn other scholars that if such a powerful figure can be brought to heel by tactics such as Hopkins's and West's aggressive use of the media and accusations of being "insensitive" or biased rather than reasoned discourse, ordinary scholars had better be extra careful not to draw their fire.

Scholars working within law schools and in numerous other noncumulative university disciplines have become trapped in a dilemma represented by the inconsistent values of the search for truth, the pursuit of consequences, and the chase after status, rewards and prestige. ${ }^{45}$ This conflict is suspended between the irresolvable tension between the reformist agendas of collective activism, the honest and balanced search for truth with integrity, and the desire for celebrity and financial reward. ${ }^{46}$ The problem is that the independent and free-minded search for truth becomes increasingly attenuated the further we move from the stance of curious inquiry and rigorous method toward active commitment to social change, particularly in the extreme forms of collective special interest activism that has accompanied essential reforms over the past two decades.

\section{AN EXAMPLE OF THE DEGRADATION OF TRUTH AND TRUTH- SEEKING}

Camus provides a view of political truth that is much like the "truths" of intense activism of the kind we might call the truths of conflict or large revolutionary truths to which we subordinate other considerations. Writing on the night in which Paris was liberated from the Nazis, he describes a kind of truth that resonates with a tone quite

44. Id.

45. The temptation to surrender to the seductions of money, power and status afflicts us all. Hoffer wams: "There is a moment in the career of almost every faultfinding man of words when a deferential or conciliatory gesture from those in power may win him over to their side. At a certain stage, most men of words are ready to become timeservers and courtiers." ERIC HOFFER, THE TRUE BELIEVER: THOUghtS ON THE NATURE OF MASS MOVEMENTS 132 (1951); see also KENNEDY, supra note 1, at 210 ("The relationship between universities and their public is more dependent on trust than on anything else. For this reason, perhaps, mendacity is viewed as the least forgivable blot on academic duty.").

46. See Bruce A. Ackerman, The Marketplace of Ideas, 90 YALE L.J. 1131, 1136 (1981). Ackerman states: "[T] he practitioner role may become so dominant that clients may pay lawyerprofessors to publish articles in law journals in the hope that a 'scholarly' article will seem more persuasive to courts than the same material submitted in a brief." Id. We have seen this occur as law professors sell their intellectual services to corporations and law firms. See infra notes 80-84 and accompanying text. 
unlike that of scholars but much like that of political academia. In The Night of Truth, he proclaims:

This night ... is the night of truth. Truth under arms and in the fray, truth sustained by force after having so long been empty-handed and unprotected. ... It is the very voice of the people and the cannons; it wears the exhausted face of the street fighters. .. . Yes, it is indeed the night of truth, of the only truth that matters, the truth that is willing to fight and conquer. ${ }^{47}$

Many of the activist scholars within law schools and noncumulative disciplines see themselves as revolutionary critics involved in a kind of guerrilla war against injustice and what they perceive to be widespread repression of themselves and the identity collectives with which they most closely identify. Nor is that perception inaccurate or necessarily inappropriate. But there are consequences when people who fill the role of scholar possess political agendas incompatible with that role or reject the tradition itself. One problem is that in such a context the academic activists' truth or method is not what we have long-considered to be the scholar's truth or method. But as Camus suggests, a revolutionary truth justifies the subordination of others, at least during the period of conflict. ${ }^{48}$ The "Large Truths" of the social revolution trump lesser truths whenever necessary or convenient. ${ }^{49}$

The ability to trump others' truths intensifies in the political disciplines of law, sociology, political science and the like. This is because the avoidance of controversy offers the path of least resistance, and because there are no clear standards about what is true or even about method. This is particularly the case when criticism of others' positions brings intense and even fanatical responses from those being criticized or who simply feel someone's statements are not consistent with, or sufficiently supportive of, their own preferred worldview. ${ }^{50}$

Another problem is that few scholars and intellectuals want to admit their own limits of knowledge or lack of courage. A strategy used by those who do not really understand what they are talking about, or

47. Albert Camus, The Night of Truth, in REsistanCE, REBELLION, AND DEATH 38 (Justin O'Brien trans., 1960).

48. See id.

49. See id.

50. Gabriel Marcel warns of the improbability of having effective discourse in a politically polarized environment: "[T]he fanatic never sees himself as a fanatic; it is only the non-fanatic who can recognize him as a fanatic; so that when this judgment, or this accusation, is made, the fanatic can always say that he is misunderstood and slandered." GABRIEL MARCEL, MAN AGAINST MASS SOCIETY 101 (G. S. Fraser trans., 1952). 
who lack the personal or intellectual courage or ability to defend their positions, has been to demean the value and possibility of truth. The unstated idea in such a denial is that if the system agrees it is impossible to achieve truth you do not have to feel guilty about not pursuing it. This conveniently frees the scholar to chase after consequences, prestige or reward. $^{51}$

One result of such a rationalization is that if there are no real standards for scholarship then new scholars following this path are largely freed of the burden of being judged on the quality of their work. The same can be said for much of what is called "voice" writing by academics because if the essence of "voice" is the recanting of a personal story in one's individual experience, beliefs, interpretive attitude and the like, then the position can be taken that "what I say is, $i s$ " and no one else has the right to say it "isn't" or that a different "story" is more legitimate.

This offers a potent shield against criticism from anyone outside the identity collective, and, since the ethic of the identity-collectives centers on the ethos of solidarity and collaborative action, there is an almost zero possibility of effective and objective criticism. ${ }^{52}$ The result is that "voice" is a power play in which one is able to preempt criticism and guarantee a zone of academic or political sovereignty for those considered part of the relevant collective. I have no problem with this form of expression through purported personal experience manifested through the device of "voice" as being a form of interesting literature or an important source of raw data for scholars' interpretations, but it is not a form of expression that should be called scholarship. ${ }^{53}$ Its power

51. See DiEKEMA, supra note 7, at $2 \mathrm{n.I}$ (suggesting that one outcome of a culture that denies the existence of intelligible standards is that the anti-tnith position of postmodernists can lead to problems with academic freedom). Diekema states that "if there is no truth but only power, the need for academic freedom ceases to exist." Id. at 3 n.l.

52. Russell Jacoby explains that "Aijaz Ahmad, an Indian scholar, has suggested that the new discipline of 'postcolonial literature,' which focuses exclusively on marginalized literature, is less a subversive field than a career move for largely upper-class Asian immigrants in American universities." RuSSEll JACOBY, THE END OF UTOPIA: POlitics AND CUltuRE IN AN AGE OF APATHY 123 (1999).

53. Consider the recent "storytelling" episode. Norma Khouri wrote a bestselling book purporting to be a true description of an "honor killing" of a friend in Jordan with whom she claimed to have grown up. The problem is that Khouri was not even raised in Jordan and left Jordan for Chicago when she was only three years old. The Guardian reports:

The author of a bestselling Australian book about the honour killing of a Jordanian woman has admitted she fabricated parts of her supposed true-life story. Norma Khouri's Forbidden Love was pulled from bookshelves last month after a newspaper reported her story was fake. The book tells of Khouri's friendship with a Muslim woman named Dalia, who was murdered by her father after falling in love with a Christian man. She 
ultimately derives from other sources than intellectual capacity and rigorous method and evidence of the kind we associate with scholarship. Its power is political, lyrical and literary.

Where this form of supposedly academic expression can lead is represented in an experience related to me by a colleague who reports that several years ago he went to a luncheon presentation in which a minority candidate for our law faculty was speaking. During the presentation, the person apparently made a serious error involving an obvious historical fact. After the presentation, when questions were asked about the error, some faculty members condemned the questioning as improper because the candidate was presenting in his own "voice" and they felt no one had the right to question the validity of what was said. ${ }^{54}$ For those trained in an intellectual culture where everything one claims is subject to analysis, criticism and evidentiary justification where appropriate, such positions are unquestionably anti-intellectual in the extreme. This, however, is precisely the principle we are being asked to abandon.

Not very long ago I experienced a personally intriguing version of "large truths" of the kind where "street fighting" advocates feel entitled to trump fact and reality in the service of what they consider a higher goal. This includes the potential that those who justify their choices and analyses through the lens of large truths to view others as objects rather than as people - a form of acceptable collateral damage required to achieve the desired goals. The lesson to which I refer occurred after I returned to my university from a trip to Bangladesh where I and some activist colleagues from throughout Asia, Latin America and Europe were working to help our Bangladeshi allies oppose a World Bank

admitted making up parts of the book - by changing names, dates, locations and characterisations - to protect herself, her family and her friends. "I'm not saying I deny that I've lied. I'm saying that I apologise to all the readers, publishers and agents out there for not letting them know my personal full story," Khouri said. ... Khouri has said in many interviews that she fled Jordan in fear for her life after the honour killing. But the Sydney Morning Herald newspaper reported last month that she had only lived in Jordan until she was three.

Author Admits Fabrication, GUARDIAN (London), Aug. 19, 2004, available at http://www.guardian.co.uk/australia/story/0,12070,1286095,00.html.

54. The rightness of the protests by the collective interests and their goals of fair treatment, opportunity and non-discrimination should not mask the fact that the language used by each collective movement (and counter-movement) has been language of attack, protest and oppositionnot reasoned discourse. It is language used as weapons to gain or defend power. It also includes the ability to inhibit others' use of language. See, e.g., MAX LERNER, IDEAS ARE WEAPONS: THE HISTORY AND USES OF IDEAS (1939) (discussing the controversies and strategies reflected in such situations as academic speech codes, criminalization of social discourse critical of groups with apparently heightened "sensitivities"). 
project that would take land use rights away from thousands of the country's rural poor. I wrote a description of the activity for interested faculty and staff and distributed it. Numerous readers told me they found the description of great interest, but one in particular did not. This colleague specializes in postcolonial critique and responded to my report with a fascinating attack based on my allegedly working on behalf of the World Bank, and presumably being paid large sums as a consultant assisting the Bank to oppress Bangladesh's poor villagers. To top it off he chastised me for sleeping in luxurious hotels and so forth. While trenchant, this intriguing "critique" was entirely false.

The reality was quite a bit different, although I suppose the fact that the report was my "story" in my personal voice rather than one offered from an allowable perspective may have been at the root of the problem. ${ }^{55}$ The truth is that my colleagues and I were members of various non-governmental organizations (NGOs) working on behalf of villagers and activist organizations in Bangladesh who were concerned about development projects they felt were destroying their way of life and eliminating their access to public lands traditionally used for agricultural purposes. Rather than living it up in luxury hotels, we stayed at the pleasant YWCA in Dhaka, at a hostel in Khulna owned by Nijera Kori, our Bangladeshi NGO partner, and on a riverboat on the fantastic Meghna River. The river sojourn ending at the Bay of Bengal and the mangrove swamps of the Sunderbans Forest included little streams of red ants crawling across my stomach at night when I was trying to sleep in the high heat and humidity while being lulled by the pounding of the engines and the inhalation of aromatic diesel fumes. All in all, it really was a truly intriguing and delightful experience but one that bore absolutely no resemblance to the one I had allegedly taken either in conditions, political mission or sponsorship.

When I brought these facts to the attention of another colleague who also works in the postcolonial area I was informed that the "truth of

55. Heather Mac Donald offers a telling criticism of storytelling and voice scholarship:

Legal storytelling has redefined the goal of legal scholarship and, with it, standards of evaluation. The purpose of stories is to "build community"-defined in racial and gender terms. Good scholarship strengthens community; bad scholarship threatens it. The implicit corollary is that only those within that community can contribute to the scholarly effort. Critical race theorists are virtually all minorities; feminist theory is almost exclusively the domain of women. Anyone who suggests applying traditional meritocratic standards to critical race scholarship (or to hiring decisions regarding those who produce it) is branded a racist. A central contention of race theorists is that meritocratic standards are a front for white supremacy.

Heather Mac Donald, Law School Humbug, CITY J. (New York), Autumn 1995, available at $\mathrm{http}: / /$ www.city-journal.org/html/5_4_a2.html. 
the situation really didn't matter" because it had created an opportunity for my first post-colonialist critic to educate others about the evils of the World Bank and so forth. I had apparently been kind enough to provide a convenient foil that allowed the message of enlightenment to be conveyed to a larger world. ${ }^{56}$ The higher good trumped the petty boundaries of truth and factual accuracy even though I was wrongly accused of doing something bad and offered up as a sacrifice.

It is possible that the critic of my description of my trip to Bangladesh was operating according to this principle of the larger, revolutionary truth in which it was acceptable to misconstrue the specific facts as a convenient vehicle by which the supposedly larger truths could be advanced. Patricia Williams's position in which she admires Tawana Brawley for lying about police officers raping her or even being raped and justifying Brawley's false accusations because "it could have happened that way" presumably fits into that same perspective. ${ }^{57}$ Of course this is a stark example of the techniques of propaganda and guerrilla war that are being used by both the Left and the Right in society. Whatever the role (or inevitability) of propaganda, falsehood and convenient ignorance in general society, they are reprehensible within an academic world where the search for truth must remain a dominant virtue. There should in fact be an inverse relationship between the duplicity of discourse in society and the commitment of scholars to the pursuit of truth according to legitimate standards in an effort to counterbalance the slide into a culture of lies, propaganda and abuse of power for political and economic gain.

This experience of others being willing to treat me as an object for the purpose of advancing their agendas, regardless of actual fact, helped me draw a line and compelled me to attempt to better understand and

56. Mac Donald offers:

In this new scholarship, factual accuracy is no longer important. Writes Stuart Alan Clarke in the Yale Journal of Law and the Humanities: "It is naive, if not disingenuous, to suggest that all that matters is the promotion of the truth." Patricia Williams's portrayal $a$ clef her teaching stint at Stanford Law School is deeply distorted, according to former colleagues there-leftists all. Williams fittingly takes refuge against such charges in the shadow of Tawana Brawley: "When students ... believed and then claimed that I had made... up [another of her personal victimization stories], they put me in a position like that of Tawana Brawley." Indeed, Brawley, whom Williams beatifies as the patron saint of victimized black women, is the perfect symbol of the movement: as Brawley's supporters on the radical left would have it, it didn't matter if her story of racial brutalization wasn't actually true, because it could have happened that way.

Id. (last emphasis added) (alteration in original).

57. See id. 
appreciate the vital roles of truth, integrity, fact and honesty. It also helped me understand the power of condemnation and the fact that I believe in certain principles I refuse to surrender in exchange for political or intellectual expedience. My conclusion as it is played out in this essay is that honesty does matter, as does the attempt to be truthful to the point of our capability. I confess being subject to a compulsion that requires me to treat each human as a person of worth and as someone deserving of fair treatment, individual respect and dignity, rather than as an object for my own ends.

Those principles of truth-seeking, honesty, and respect for individual human dignity and integrity are part of my code of existence and I am not about to change them. Political collectives-postmodernist, conservative, fascist, Leftist, Rightist or otherwise-the members of which refuse to accept the principles of human dignity, intellectual honesty and the commitment to following the path of truth and validity are my opponents. The practitioners of such anti-humane and dishonest approaches are neither scholars nor even real intellectuals whether serving within academia or as "public intellectuals." They have increasingly become political opportunists and shills for their sponsors and are a deplorable combination of intellectual mercenary, ideologue and demagogue who separate us rather than help us build the bridges and networks that are essential for mutual understanding and cooperative solutions. These opportunists, ideologues and mercenaries produce division and strife among people who should be working together toward common goals. One reason this fragmentation is occurring is that if you can not rely on the honesty and integrity of a scholar or academic then there is no core of truth and legitimacy-only an amorphous and malleable reality manipulated in ways that produce a sense of cultural distrust, cynicism and betrayal.

\section{POSTMODERNISM AND "TRUTH-VALUE"}

Judicial analysis and legal scholarship are the ultimate postmodernist form of reasoning-power-driven, culturally bound, and absolutely political while preserving its masks by pretending it is eternal and natural even if its positivistic relativism is otherwise undeniable. It is intriguing, however, that while many see the fact that the conditions or "truths" in human societies are socially constructed as a negative, this characteristic can also be a positive consideration. The ability to construct truths offers the ability to make choices about ways to improve our system. It is much like the dream of Reason in the context of such 
dualisms as mind and body, flesh and spirit, in which the power of Reason was argued to be the divinely or universally granted faculty that humans could apply to perceive reality and to grow toward perfection. ${ }^{58}$ The dream of Reason offered the opportunity to transcend our animal natures, reflected in our sinful and bestial tendencies, and aspire toward a more perfect or pure level. The power to transcend what was considered our base biological self also imposed the responsibility to seek to progress toward that ideal of enhanced humanity.

The problem - now and historically - is that this requires the ability to agree on what might be a better way of being and what aspects of our animal natures we can or should overcome. Truth has been thought to play an important role in this process of social, moral and political evolution. If, however, truth is degraded in fact or as an ideal, what happens to the ability to communicate or work toward some heightened standard of perfection on both the social and individual planes? If truth is denigrated either in practice or as an ideal, the risk is that we lose any coherence within our social order and eliminate the ability to share grounding principles for our society.

A scholar critical of postmodernism argues: "Truth, among postmodernists, is whatever you can get away with saying in whatever specific context you find yourself. Power lies in the context (the prevailing mentality) and, thus, power becomes truth." warns that "an increasing number of professors no longer believe in the 'pursuit of truth' because they no longer believe that truth exists." ${ }^{, 60} \mathrm{He}$ adds:

They do, however, believe in politics - and most especially in identity politics. Thus, efforts to equalize genders, races, and cultures become the value that academic freedom presumably protects, while the criteria of truthfulness (as argued through evidence and rational argument) is seen as that which continues to exploit women, people of color, homosexuals, the poor and other victimized groupings. Not surprisingly, the two conditions usually overlap; and ... defending academic freedom is harder now than at any time in this century. ${ }^{61}$

The argument developed here is that the postmodern position on the nature of truth is correct in some contexts but too often used in a

58. See Anthony GotTlieb, The Dream of REASON 25-26, $91-92$ (2000).

59. DIEKEMA, supra note 7 , at 2 n.l.

60. Sanford Pinsker, Tenure Can Rescue the Academy, WASH. TIMES, Oct. 31, 1996, at A23; see also Bradford P. Wilson, Politicizing Academic Freedom, Vulgarizing Scholarly Discourse, Chron. OF Higher EdUC., Dec. 19, 1997, at A52.

61. Pinsker, supra note 60, at A23. 
misleading and deliberately strategic fashion in that the criticisms of the nature and possibility of truth are typically overdone, incomplete or politically biased in ways aimed at deconstructing an existing orthodoxy with which the critic disagrees. It should also be noted that postmodernists offered nothing new in their argument that truth was relative and socially constructed. ${ }^{62}$ Their willingness to aggressively put forward the insight that particular truths are also often the manipulative products of a power hierarchy is, however, an important warning when we examine positions and policies, including those manifested through law and legal institutions, in order to test them for unfair discrimination as well as the legitimate distinctions inevitably drawn in any real political system. In dealing with truth and truth-seeking it is an equally troublesome fact that the analyses are often applied to different contexts than are appropriate for the particular kinds of truth at issue or the functions to which a specific variety of truth is appropriately applied. ${ }^{63}$

When we speak of truth and truth-seeking, we need to examine the various propositions from the perspective of their complexity and functions. When we look at the ideas of truth and truth-seeking, we tend to use them as overly general terms that have a variety of quite different meanings and functions. ${ }^{64}$ Whether viewed as an integrated system with multiple facets or as a system in which the independent interpretations of what passes for truth is determined by the functional needs of a specific political, intellectual, or systemic element of society, "truth" is an

62. See, e.g., GotTLIEB, supra note 58, at 119. In speaking of the Sophists, Gottlieb relates: [The] fact of varying perceptions is precisely the problem that Democritus sought to answer when he dismissed subjective judgements of sweetness, bitterness, heat, cold and so on as mere 'convention' and posited instead his objective 'atoms and void'. Protagoras answered the problem on behalf of the Sophists with a different and apparently shocking idea: instead of dismissing subjectivity, he positively embraced it. What I perceive is true for me, and what you perceive is true for you. He held that there is no universal truth about the everyday world of experience, but that this does not mean that there is no truth about it at all. Quite the reverse: there is, if anything, an abundance of truth. For what each person perceives is the truth for him. That is what Protagoras meant when he famously said that 'Man is the measure of all things.'

Id. Gottlieb goes on to say, "This sort of view is known as relativism, because it holds that truth is relative to each believer, or, more often nowadays, relative to each group or community of believers." Id.

63. See Richard HofSTAdTER, ANTI-INTELlectualism IN AMERICAN LifE 428 (1962) ("Today knowledge and power are differentiated functions. When power resorts to knowledge, as it increasingly must, it looks not for intellect, considered as a freely speculative and critical function, but for expertise, for something that will serve its needs.").

64. I am currently writing an essay on what I call the "forms of truth." This offers (at this point) twelve distinct forms ordered within categories I have labeled as "Verifiable [almost] Truths," "Legal Dispute Truths," "Political Truths," "Humans-in-Community Truth," and "Received and Revealed Truth." Each has a distinct function, goal and method. 
extremely variegated set of ideas. This analysis becomes important when we consider the attacks on the ideal of truth that have been made by postmodern writers and the increasing arguments that truth is ephemeral, discriminatory, relative, culturally bound or impossible to achieve. ${ }^{65}$

Many of the newly anointed scholars seem to consider the most appropriate use of their privileged position to be self-interested political activism rather than serious and balanced inquiry and formulation of action-oriented solutions based on the best evidence. I suggest that one result is that the concept of "learnedness" has been replaced with aggressive activism that gives short shrift to the traditions of knowledge and learning. This cultural shift within academia has gone on for more than two decades and one result is that we have birthed an entire generation of academics in the noncumulative disciplines who do not know much of anything other than attack. The primary commitment of these academics is to advance the agendas of their identity group through political organization and special interest critiques. This posture has become the norm rather than the provocative exception.

But as a scholar who believes that the scholar's pursuit of trutheven though often flawed-is a vital element in the Western cultural tradition, I feel compelled to challenge the assault on the ideal of scholars' truth-seeking and to argue against a simplistic conception of truth and its functions. This assault on the ideal obviously heightens the conflict between those who see themselves as defenders of the

65. See, e.g., ANTHONY Giddens, The CONSEQuenCES OF MODERNITY (1990). Giddens argues:

The condition of post-modernity is distinguished by an evaporating of the "grand narrative"- the overarching "story line" by means of which we are placed in history as beings having a definite past and a predictable future. The post-modern outlook sees a plurality of heterogeneous claims to knowledge, in which science does not have a privileged place.

Id. at 2. He continues:

Modemity is constituted in and through reflexively applied knowledge, but the equation of knowledge with certitude has turned out to be misconceived. We are abroad in a world which is thoroughly constituted through reflexively applied knowledge, but where at the same time we can never be sure that any given element of that knowledge will not be revised.

Id. at 39 .

Even philosophers who most staunchly defend the claims of science to certitude, such as Karl Popper, acknowledge that, as he expresses it, "all science rests upon shifting sand." In science, nothing is certain, and nothing can be proved, even if scientific endeavour provides us with the most dependable information about the world to which we can aspire. In the heart of the world of hard science, modernity floats free.

Id. (footnote omitted). "No knowledge under conditions of modernity is knowledge in the 'old' sense, where 'to know' is to be certain. This applies equally to the natural and the social sciences." Id. at 40 . 
traditional ideals of the university centered on the search for truth through the combination of rigorous study, methodological mastery and commitment to evidence as the basis of interpretation (even if those ideals were in some ways overstated and too often dishonored) and the collective-academics who have flooded into the "soft" or noncumulative disciplines of the changing university and infused the general world of intellectual commentary with calculated political positions and ideological strategies.

Although the undermining of the ideals of truth and truth-seeking has been contributed to by numerous sources, including commercial advertising and political propaganda aimed at acquiring and maintaining control, it may be useful to reflect briefly on a strand of intellectual activity, postmodernist thought in Europe, that influenced American academic thinking in the noncumulative disciplines over the past thirty years. Although one may argue that its period of strong explicit application has passed, there are long-term effects from the arguments made by postmodernists and the way they now infiltrate our intellectual and political ethos in relation to the connection drawn between truth and power.

There is a hidden danger in the assertion that "power becomes truth," even for those relying on that assertion to undermine the traditional positions they seek to supplant. Truth is entirely relativistic unless the statement's real meaning is that power becomes taken as truth because those holding power have the ability to control the terms and conditions being defined as "true." The trap is that if truth is entirely relativistic then those who complain of historical or ongoing injustices have cut out the ground from beneath the foundations of their own arguments.

The questions that underlie this position are: From where is legitimacy derived? If truth is relative and socially constructed within cultures to serve power, then from where do we summon legitimacy, authenticity and authority? When truth is defined by the particular power holder of the moment, and legitimacy is derived from power, there would have been nothing wrong with the subordination of women, minorities, the poor and so forth. The paradox is that to say those discriminatory conditions were unjust requires a belief in a set of underlying truths that are either non-relative or that represent a set of irreducible principles which we collectively choose to treat as nonrelative because we intuitively know the alternatives are destructive.

Conversely, if "power becomes truth" based on the inevitable tendencies of those in power to define its terms, then to the extent that 
previously subordinated groups have now achieved some semblance of power the same conditions must apply to their manipulation of language and agendas. This makes them subject to the same critique of abusing power to achieve and serve their own ends. This means that as feminists and other previously subordinated interests gain power, they are just as likely to construct "truths" that serve their ends. And to the extent that we follow Acton's warning that "[p]ower tends to corrupt and absolute power corrupts absolutely,"66 this suggests that women or any other identifiable group in power will be no less self-serving, discriminatory and abusive than the men they critique.

The irony is that the newly subordinated, who had been in power or at least were substantial beneficiaries of the deposed power-regime, thus become the opposition while the architects of the new power-regime become the oppressors. This means that the values and "truths" of the newly dominant group are no more valid in any ultimate sense than any others. They are simply more powerful and therefore more "true" in this specific historical moment. This is nothing more than a simple variation on the assertion that "might makes right." In this world of plastic-truth the proto-Hobbesian would already be developing strategies to replace the new tyrants who follow the inevitable behavior of those in power by altering the culture they control in ways that benefit their own interests and inhibit opportunities for others.

While the postmodernist assertion that "power becomes truth" is therefore of some use as a cautionary principle, there must be some set of "ultimate truths" on which we ground our society-even if they are negotiated and refined over generations rather than revealed. I suggest that there most likely are a set of ultimate truths by which humans would naturally order their societies if not subjected to overwhelming force and intimidation. This is what Rawls sought to develop in $A$ Theory of Justice in the sense that his "Original Position" essentially offered a barely concealed formulation of the Golden Rule or the principle "do unto others as you would have them do unto you," offered not as a religious belief but as a basic principle of social ordering. ${ }^{67}$

66. John Emerich Edward Dalberg-Acton, Essays on Freedom and Power 364 (Gertrude Himmelfarb ed., 1948).

67. See JOHN RAWLS, A THEORY OF JUSTICE 102-68 (rev. 1999). Trying to avoid this dilemma is of course why Rawls posited his "Original Position" in this work. In the "Original Position" the persons creating the rules of allocation for society operated behind a veil of ignorance that meant they did not know anything about their own position in the society-to-be. Id. at $118-23$. The thesis is that the rules would be fairer in order to allow for better treatment in case they were one of the less advantaged members of the new society. Id. Of course, Rawls's device was both hypothetical and impossible. 
Implicit within this idea of a healthy person perceiving the political community in a way that is most likely to produce cooperative and altruistic behavior and reduced strife is the recognition that there are good and bad ways to order a society. This represents the assertion of a truth concerning the orientation and behavior of humans in society that, if we actually heeded, would result in a qualitatively higher order of a cooperative society than we have heretofore experienced. This represents an ideal and, I argue, a key social truth of humans in society that transcends a particular culture and moment. Regardless of postmodernist interpretations, I suggest the real problem is our failure to accept a limited set of basic truths about humans in society rather than a failure of human truths themselves. ${ }^{68}$ This offers an ideal to which we can aspire and a standard against which we can judge ourselves and our societies. Otherwise we are cast adrift into a Hobbesian state of nature characterized by unending struggle, strife and conflict as we maneuver to survive and conquer. ${ }^{69}$

I argue that such principles are either absolutely true in the sense of the necessary ordering of human societies under the Rule of Law or that they are so vital to the legitimacy of human societies and a source of just operation that without them we devolve rather than evolve. The principles can be true a priori or a posteriori. A poorly understood fact is that the postmodernist position on the relativistic and powerconstructed nature of "truth" creates a dangerous conundrum for those who assert it because if the only "truth" is that which is achieved by power, then the arguments of feminists and other critical movements that they have been treated unfairly or unjustly carry little moral weight. To the extent they were subordinated by a white-male establishment that was capable of creating and wielding sufficient power to allow them to mold a "truth" that discriminated against women, minorities and others, it could be claimed that the system was operating "justly" because the "true" terms were whatever its control of the instruments of power allowed the establishment to get away with.

68. See David Barnhizer, Prophets, Priests, and Power Blockers: Three Fundamental Roles of Judges and Legal Scholars in America, 50 U. PITT. L. REV. 127 (1988) (discussing ultimate truths); see also GeORGE P. Fletcher, BASIC CONCEPTS OF LEgAL THOUGHT 139-54 (1996) (analyzing ultimate values).

69. See Thomas Hobbes, Leviathan 185 (C. B. MacPherson ed., 1968) (discussing "a warre ... of every man, against every man”). 


\section{THE DEGRADATION OF THE IDEALS OF TRUTH AND TRUTH- SEEKING}

Although the underlying desire to rectify the consequences of historical and still ongoing discrimination against minorities and women is absolutely admirable, there has been a subordination of virtually all considerations other than our desire to achieve political change. The blindness created by political activism is one source of anti-intellectual and anti-scholarly pressures, but it is not the only cause. Another kind of motivational distortion also occurs when a scholar pursues status, financial reward and power rather than understanding. ${ }^{70}$

The gap between the dictates of truth and consequences widens when the scholar is personally interested in the analysis or pursues a specific outcome, and becomes a chasm when the scholar works from within a political collective whose members are using the vehicle of scholarship as a strategic tool for their own ends. When powerful collectives committed to common agendas and political transformation control the system the independent search for truth is diluted, diverted and even corrupted. Truths are assumed and the goal is no longer insight and understanding but achieving desired political outcomes.

The problem is compounded because there are limited ways of establishing the authenticity of scholars' assertions in noncumulative disciplines such as law, philosophy, ethics, politics, religion and the like. $^{71}$ It is also masked because it is in such disciplines that corrupt motives or the inability to gain clear perspective are easily concealed behind elevated rhetoric. It is like we are Michelangelo's Unfinished Slaves trapped in blocks of marble in the Accademia del Designo. We twist and turn and even succeed in partially extricating ourselves from the stone that not only holds us but is the base material from which our form is created. But our ability to step outside the context of our creation and existence to become completely separate or "alive" will always be limited. I have often thought it must be even worse for the Slaves because they are condemned to gaze for eternity on the shining form of

70. See KENNEDY, supra note 1 , at 210.

71. See BRINTON, supra note 2, at 13, 415. Brinton spoke of noncumulative knowledge as knowledge relating to wisdom, human nature, values and morality. He states:

Men ... make certain propositions, entertain certain ideas, about men, about right and wrong action, about beautiful and ugly things. Over two thousand years ago, men of letters were writing in Greek on these matters ... . But our contemporary men of letters are today writing about the very same things the Greek men of letters wrote about, in much the same way and with no clear and certain increase in knowledge. Id. at 9 . 
Michelangelo's David who represents the synthesis of truth, objectivity and the ultimate beauty of form and achievement.

The postmodernists were correct when they argued that human truths (at least in the noncumulative disciplines) were socially constructed (and therefore products of and in the interests of those who possessed the power to construct). ${ }^{72}$ But they helped create a selffulfilling prophecy in which the conversion of almost everything to illegitimate power, manipulation and constructed truth designed to serve specific agendas over a very short period of time, was intensified and accelerated. In so doing, they destroyed the validity of the ideal and weakened the search for truth as a positive value. ${ }^{73}$

Jules Henry has argued that the values and institutions of the Twentieth Century reversed the truth-seeking spirit of several millennia, describing the conditions of the new society as a "culture of lies." $\mathrm{He}$ explains:

Ancients of our culture sought clarity: Plato portrays Socrates [as] tirelessly splitting hairs to extract essential truth from the ambiguities of language and thought. Two thousand years later we are reversing that, for now we pay intellectual talent ... to amplify ambiguities, distort thought, and bury reality.... One of the discoveries of the twentieth century is the enormous variety of ways of compelling language to lie. ${ }^{74}$

The malady Henry described nearly a half-century ago has penetrated deeply, infecting our culture at all levels, including that of university and law school scholars. The value of truth has plummeted in American society and this has been caused by powerful forces. These include the extreme monetization of virtually everything along with the politicization of all institutions to the point that none can be trusted. ${ }^{75}$

72. See id. at $11,14-15,415$.

73. In a voice that directly contradicts the postmodern position, Krishnamurti argues:

The man who is seeking reality spontaneously becomes the right kind of citizen, which is not according to the pattem of any particular society or government. So, students as well as teachers must work together to bring about the release of this tremendous energy to find reality, God or truth. In your very seeking of truth there will be discipline, and then you will be a real human being, a complete individual, and not merely... limited by ... particular society and culture.

J. KRISHNAMURTI, THINK ON THESE THINGS 187-88 (D. Rajagopal ed., 1964).

74. JULES HENRY, CUlTURE AGAINST MAN 91 (Vintage Books ed. 1965). In criticizing the effects of market-morality Jules Henry argues that: "[ $[$ ]he heart of truth in pecuniary philosophy is contained in the following three postulates: Truth is what sells. Truth is what you want people to believe. Truth is that which is not legally false." Id. at 50 .

75. Mitch AlbOM, TUESDAYS WITH MORRIE: AN OLD MAN, A YOUNG MAN, AND LifE'S GREATEST LESSON 124-25 (1997). 
The result is that the meaningfulness of many of our activities is determined according to their market value, including the extent to which they lead to status or power for the scholar. Of equally compelling significance is the emergence of a celebrity culture parading an endless stream of anti-heroes in relation to which we assess the standards of our success or failure in life. ${ }^{76}$ The loss of positive deep values of a strong moral, ethical or spiritual weight has led to the rise of a compensatory religiosity by which we seek grounding from divine sources in an effort to counter the amoral chaos found throughout society. These factors coalesce and often produce fanaticism, the drive for power and the need to belong. ${ }^{77}$

Profit, status and prestige, political agendas and a decline in the quality of method, substance and discipline have all contributed to the degradation of the ideal of truth and the rejection of that responsibility by too many new "scholars." Nor should we be surprised. Those who become academics are not reborn with intellectual, moral and spiritual purity on entry to their disciplines. As the culture becomes politicized, chooses greed and selfishness as primary "virtues," and is educated by generations of teachers who themselves lack discipline and know very little of substance, how could we expect the results to be anything but decline and degradation of traditional principles and commitments? The blind are truly leading the blind.

"We've got a form of brainwashing going on in our country," Morrie sighed. "Do you know how they brainwash people? They repeat something over and over. And that's what we do in this country. Owning things is good. More money is good. More property is good. More commercialism is good. More is good. More is good. We repeat it-and have it repeated to us-over and over until nobody bothers to even think otherwise. The average person is so fogged up by all this, he has no perspective on what's really important anymore."

ld.

76. See Daniel J. Boorstin, The IMAGE: A Guide to Pseudo-Events IN AMERICA 51 (25th Anniversary ed. 1987). Boorstin observes:

The making of the illusions which flood our experience has become the business of America, some of its most honest and most necessary and most respectable business. I am thinking not only of advertising and public relations and political rhetoric, but of all the activities which purport to inform and comfort and improve and educate and elevate us: the work of our best joumalists, our most enterprising book publishers, our most energetic manufacturers and merchandisers, our most successful entertainers, our best guides to world travel, and our most influential leaders in foreign relations. Id. at 5 .

77. Merton argues that: "modern man is beset by anxiety and a feeling of insecurity. He tries to adapt to changes he cannot comprehend. The conflict of propaganda takes the place of the debate of ideas." Robert K. Merton, Foreword to JACQUES ElluL, THE TECHNOLOGICAL SOCIETY, at v, vii (John Wilkinson trans., 1964). 
A result is that the degraded values of our "culture of lies" now serve not only as the foundation of virtues of the general society but as the values of the individuals who enter the academic realm. ${ }^{78}$ If the commitment to truth and rigorous method in law school and university teaching and scholarship have undergone a transformation or degradation it is entirely unsurprising this has occurred. The change has been exacerbated by three main factors. These include the waning in the academic community of any belief in our ability to attain absolute truth through intellectual inquiry. This is further intensified and accelerated by the postmodern turn that inextricably linked power and the rhetoric of truth as a political and instrumental device masquerading as an intellectual argument, and the conversion of academics into advocates, ideologues and demagogues in pursuit of specific outcomes. ${ }^{79}$

Law professors are inundated with opportunities to serve others' interests and are pursued by powerful interests who seek to take advantage of the scholars' cachet as paragons of intellectual wisdom and authority. When this occurs their intellectual integrity and credibility are compromised, regardless of whether they sincerely think otherwise. ${ }^{80}$ They become workers in service of power, a phenomenon Jacques Ellul warned about in which a society's intelligentsia in a "technological society" becomes little more than servants to the most powerful interests. ${ }^{81}$ The reality of the seduction of scholars into the service of power was made clear by a report revealing that Exxon funded articles by several of the most prominent law professors in the country, including Chicago's Cass Sunstein, and then used the results to support its position on appeal in opposing the award of punitive damages levied

78. One of the responsibilities of the scholar is to not become a voice for external interests. It is to comment on the world, not to be captured by it. J. H. HEXTER, MORE'S UTOPIA: THE BIOGRAPHY OF AN IDEA 125 (1952) (describing the effects of being within a system rather than being an innovator attacking it from outside). Hexter concludes:

If the unattached intellectual remains an innovator, his only alternative to coming to terms with the above sad fact [that "they rarely get a hearing from the men who have the power to put their proposals into execution"] is to change his situation, to cease to be an ld.

unattached intellectual, and to become either a revolutionary or a bureaucrat.

79. See David W. Noble, The Paradox of Progressive Thought 7 (1958) (discussing the idea that we no longer believe human reason offers the "little backstairs door that ... serves as the secret entrance way to knowledge") (quoting CARL BECKER, THE HEAVENLY CITY OF THE EIGHTEenTH-CENTURY PHILOSOPHERS 31 (1932)).

80. See KENNEDY, supra note 1 , at 210 (observing that one of the worst sins a scholar can commit is that of mendacity).

81. See Merton, supra note 77, at vii. 
against it for the oil spill in Alaska. ${ }^{82}$ When the questionable relationship was revealed and challenged, Sunstein and the other law faculty who received money from Exxon took the position, at best naïve, that their positions on punitive damages would somehow be virtuously uninfluenced by the bargain they made with Exxon.

Of course the seduction is not limited to legal scholars. Prominent British historian Roger Scruton was recently embarrassed when it was revealed that he had received substantial compensation from a tobacco company in the period when he had written numerous op-ed pieces presenting themes of use to positions being taken by the tobacco industry. ${ }^{83}$ The fact that this position could be taken by a highly respected historian exposes the kind of disingenuous value system and self-deception practiced by intellectuals who allow themselves to be captured by the power and wealth of clients and other sponsors of great magnitude. ${ }^{84}$

Because none of the noncumulative disciplines' truth-seeking methods are unassailable from the perspective of empirical validity grounded on demonstrable and strong evidence sufficient to persuade all reasonable people, such disciplines are vulnerable to distortion, ideology and abuse by politicized scholars with agendas other than truthseeking. ${ }^{85}$ Each noncumulative system requires foundational

82. Elizabeth Amon, Exxon Bankrolls Critics of Punitives: Then It Cites the Research in Appeal of \$5.3B Valdez Award, NAT'L L.J., May 17, 1999, at A1.

83. Alexander Stille, Think Tank: Advocating Tobacco, On the Payroll of Tobacco, N.Y. TIMES, Mar. 23, 2002, at B9. Nor was it "small change." Stille reports:

The Guardian published a leaked e-mail memorandum that Mr. Scruton and his wife, Sophie, sent to Quentin Browell, an executive at Japan Tobacco International, which sells numerous brands of cigarettes, including Camel, Winston and Salem. In the memo Mr. Scruton offered to orchestrate a major pro-smoking publicity campaign and urged that his monthly retainer be increased to 5,500 pounds (about $\$ 7,800$ ) from 4,500 pounds (about $\$ 6,400$ ).

Id.

84. Cf. HEXTER, supra note 78, at 136-38. (arguing in his analysis of Thomas More and his decision whether to remain an external critic or to become a King's Counselor that the Prince always wins. We are covertly or overtly shaped into paths that advance the Prince's interests.) Hexter adds:

Men are called into a prince's service only to help the prince work out expeditious ways for getting what he is determined already to have at any cost. Instead of leading him along paths that they believe to be good, they soon find that they are having their brains picked to ease his way along paths they know to be bad. Such talents as they have end up by being deployed not to support but to subvert the causes closest to their hearts. Id. at 137.

85. JUNG, supra note 6 , at $2-3$ (waming that "[ $t$ ] he mass crushes out the insight and reflection that are still possible with the individual, and this necessarily leads to doctrinaire and authoritarian tyranny"). 
assumptions and choices-often inchoate and inherited from past training and experience. ${ }^{86}$ What emerges in the various disciplines of noncumulative knowledge are systems filled with unarticulated (and often inarticulate) assumptions that reflect the fact that both traditional and activist scholars have built their "intellectual houses" on foundations of sand, self-interest and personal preference and ideology. If their foundational assumptions are challenged on the basis of their ultimate "provability" the house collapses. Certainly this is why postmodern deconstruction was seen as so dangerous by many and rejected-both because it threatens the grounding principles on which their preferred social order rests and it calls the validity of their preferred interpretations into question.

Nor is the fear of a weakening of the social fabric invalid because our noncumulative knowledge is based on a limited set of often unstated and unprovable political, moral, religious and philosophical assumptions. This intrinsic and foundational weakness means that deconstructive critiques can undermine the foundations of virtually any assertion and in fact they are intended to accomplish this outcome. This dilemma is intensified when the social issues at stake involve competing interpretations of right and wrong, as well as being based in the minds of believers in a "deep" system, such as the conviction that the principle to which a particular set of "disciples" are committed is an emanation of divine revelation or is based in the belief that individual (or collective) human "rights" exist that cannot be trumped by anything. ${ }^{87}$

Conversely, in a society that has lost any grounding in broadly consensual values considered to be of a weight sufficient to support

86. See WOLFF, supra note 7 , at 15 . Wolff suggests this is a problem even in the empirical disciplines we tend to think are firmly grounded in unassailable objectivity and clear proof. He observes:

At any given moment, a scientific discipline is like a nomadic community moving through new and uncharted territory. There is a frontier along which exploration is taking place, a settled and well-established interior in which the accepted body of scientific truth is to be found, and a hinterland of old hypotheses, discarded theories, and exploded superstitions.

Id.

87. See HOBBES, supra note 69 , at $188-91$. Hobbes speaks of six considerations that lead to the weakening and even the dissolution of a political commonwealth. These are:

[1] That every private man is Judge of Good and Evill actions... [2] [W] [atsoever a man does against his Conscience, is Sinne .... [3] That Faith and Sanctity, are not to be attained by Study and Reason, but by supernaturall Inspiration, or Infusion ... . [4] That he that hath the Soveraign Power, is subject to the Civill Lawes.... [5] That every private man has an absolute Propriety in his Goods; such, as excludeth the Right of the Soveraign.... [6] That the Soveraign Power may be divided. Id. at $365-68$. 
collective decisions, the deconstructive methodology is a destructive weapon against any value-based position. Deconstructionists are like medieval sappers who developed techniques for burrowing beneath seemingly impregnable castle walls to weaken their supporting foundations and causing a breach in the defenses leading to collapse and defeat-i.e., "sapping" the strength from the defending system. The process may be largely invisible and occur over an extended period of time, but the consequences-for good or ill-are quite real. ${ }^{88}$

\section{CONCLUSION: RESISTING THE DEGRADATION OF THE IDEAL}

Central to the argument offered here is recognition of the need for a pragmatic but idealistic understanding of the nature and functions of truth and truth-seeking within political systems of the kinds that characterize Western democracies. ${ }^{89}$ Although some will disagree with the view, I feel comfortable in the assertion that there must be strong ideals on which a political system is anchored and that we need to choose those that preserve vital strands of the cohesive dynamics essential to our form of political community.$^{90}$ This is in fact arguably more important today in the new forms of neo-democratic political systems that characterize Western Europe and America-systems in

88. In discussing his theme of how intellectuals must act in transforming transitional societies Mill suggests the need to implement strategies that almost invisibly undermine a dominant orthodoxy over a substantial period, rather than to attempt a direct attack that will be easily recognized and defended against with the full power of the orthodoxy. See JOHN STUART MILL, Theism, in THREE ESSAYS ON RELIGION 125, 256-57 (1874) [hereinafter MILL, Theism]; John Stuart Mill, On Liberty, in ESSENTIAL WORKS OF JOHN STUART MILL 249 (Max Lemer ed., Bantam Matrix 1965); JOSEPH HAMBURGER, JOHN STUART MILL ON LIBERTY AND CONTROL 18-20 (1999) (stating that Mill's mission was to cause a restructuring of society and humanity from the ground up).

89. GIDDENS, SUPRA note 65 , at 37 . Giddens explains:

In traditional cultures, the past is honoured and symbols are valued because they contain and perpetuate the experience of generations. Tradition is a mode of integrating the reflexive monitoring of action with the time-space organisation of the community. It is a means of handling time and space, which inserts any particular activity or experience within the continuity of past, present, and future, these in turn being structured by recurrent social practices. Tradition is not wholly static, because it has to be reinvented by each new generation as it takes over its cultural inheritance from those preceding it.

Id.

90. John Stuart Mill stated this important role of the deeply grounded belief or ideal even while he implicitly sought to undermine the function of traditional institutional Christianity and replace it (rather optimistically) with a "Religion of Humanity" that would free the human to develop to the highest level during one's life rather than diverting attention to what he considered a selfish possibility of an afterlife. See, e.g., JOHN STUART MILL, Utility of Religion, in THREE ESSAYS ON RELIGION 69, 109 (1874); MILL, Theism, supra note 88, at 255-56. 
which the internal diversity and complexity are so extreme that they are submerging any sense of cooperative community and shared values. ${ }^{91}$

One might argue that the most crucial role of a core set of ideals is to generate for a culture the kind of binding "dark force" scientists have postulated is invisibly at work in the universe to maintain the integrative structure of the system. I argue that truth and truth-seeking are among the ideals that serve this function for Western societies but they are not the only virtues. Oddly enough, at least on the surface, is that such purportedly pejorative terms as hypocrisy, propaganda and ideology have equally vital roles in the actual operation of political communities, including ones governed by the Rule of Law, although we cannot admit their importance due to their negative connotations. ${ }^{92}$ The fact, however, is that the roles of such anti-virtues as propaganda, hypocrisy and ideology are intensified in a complex democratic multiplex such as we

91. Clearly our modern "democracies" bear little resemblance to the Athenian form. Aristotle concludes that even with its numerous flaws, democracy is the best real option available to humans. The three true forms of government were kingly rule, aristocracy, and constitutional government. The three corrupted forms were tyranny, oligarchy, and democracy. See ARISTOTLE, THE POLITICS OF ARISTOTLE paras. 1267b22-1269a24 (Peter L. Phillips Simpson trans., 1997). Aristotle considered democracy the best form in the real world because it had the greatest likelihood to serve the common good of all citizens while the other forms all tended toward the interests of specific classes. Among the fundamental distinctions between the modern form and the Athenian version with which Aristotle was familiar is that ours is much more diverse in its voting constituencies and is far beyond the modest population limits suggested by Aristotle as necessary for a democracy to function. He in fact said that, once a system went beyond the kind of limited scale that characterized the Athenian democracy, something other than democracy existed because it transcended the capabilities of that political methodology. In Athens, it was also true that voting citizens did not include women, barbarians or aliens, or slaves. This made for a homogenous polity, unlike our existing diverse nation of strangers. See id. at paras. $1269 \mathrm{~b} 12-1269 \mathrm{~b} 39$.

92. Trying to gain a fair sense of the extent to which we are operating in a longstanding tradition or creating a new and still forming tradition representing a radically changed political system that never existed outside recent history adds to our dilemma. Giddens argues for a "discontinuist" interpretation in which modern institutions are "in some respects unique-distinct in form from all types of traditional order." GIDDENS, supra note 65 , at 3 . He claims we need to displace the evolutionary narrative by which we understand our society in history due to factors that include the pace of change, the scope of change, and the intrinsic nature of modern institutions where some now exist that were not found traditionally. $I d$. at 6 . This perspective is echoed by Michel Foucault who argues that a new form of the political state with a different structure has been developing since the sixteenth century. Michel Foucault, The Subject and Power, in HUBERT L. DReyfus \& PaUl Rabinow, Michel Foucault: Beyond Stucturalism and Hermeneutics 208,213 ( $2 \mathrm{~d}$ ed. 1983). The fact of significant differences is undeniably true, but it must also be admitted that, if one is a postmodernist and is seeking to produce a different line of reasoning and values, this is also precisely the claim one would make. Given the immense infusion of non-Western cultures, institutions and values that Western democracies have been experiencing, such an argument helps justify claims to the legitimacy of multicultural politics and the need for a new form of interest group politics and values. Of course there have been numerous transitions in political form throughout our recorded history, and an alternative argument is that "the more things change, the more they stay the same." 
have allowed to come into being because there is no strong binding ideal on which all will agree. ${ }^{93}$

While we might argue that this degradation of the value of truthseeking and scholarly integrity generates a heightened responsibility to strive even harder to protect and preserve the search for truth and wisdom, the simple fact is that in a complex and extraordinarily stressful world, the search for truth is both extremely hard and time consuming. In a society of extraordinary complexity, honest and richly textured noncumulative analysis requires an enormous array of knowledge, insight and continuous hard work for which there are relatively few external rewards. The task is so difficult that it is far easier to accept someone's claims and spend one's own time in other pursuits, particularly when a challenge to those claims is likely to incur the wrath of a political collective.

93. Aristotle concluded that democracy could not function beyond a certain level and mixture of population. Aristotle warns:

There is a limit to the size of a city just as there is to everything else. . . For if any one of these is either too small or too large in size, it will not have the power that belongs to it but will sometimes wholly forfeit its nature and sometimes be in a base condition.

ARISTOTLE, supra note 91 , at para. 1326a35. He argues that the size and composition of a city-state is important because:

A city's acts are those of its rulers and of its ruled subjects, and the work of the ruler is to command and pass judgment. But with respect to passing judgment on matters of justice and distributing offices according to merit, the citizens must know what each other is like, for where it happens that they do not, these matters of judgment and offices must be in a base condition. For it is not just to decide them in an offhand way, but that is manifestly what happens where there are many people. Further, foreigners and resident aliens could easily get a share in the regime because, given the excessive numbers, escaping detection will not be hard.

Id. at para. $1326 \mathrm{~b} 7$. 
$* * *$

HeinOnline -- 33 Hofstra L. Rev. 1240 2004-2005 